\title{
STABILITY AND DURABILITY OF SAWDUST ASH-LIME STABILISED BLACK COTTON SOIL
}

\author{
I. N. Obeta ${ }^{1, *}$, C. C. Ikeagwuani ${ }^{2}$, C. M. Attama ${ }^{3}$ and J. Okafor ${ }^{4}$ \\ $\mathbf{1 , 2 , 3 , 4}$, DepARTMENT OF CiVIL ENGINEERING, UNIVERSITY OF NigeRIA, NSUKKA, ENUGu STATE. NIGERIA \\ E-mail addresses: ${ }^{1}$ ifeanyi.obeta@unn.edu.ng, ${ }^{2}$ chijioke.ikeagwuani@unn.edu.ng, \\ 3.chuka.attama@unn.edu.ng, ${ }^{4}$ j.okafor@gmail.com
}

\begin{abstract}
The assessment of the durability of twelve cylindrical samples of black cotton soil, a well-known problem soil, stabilized with a combination of $4 \%$ lime and $16 \%$ sawdust ash were carried out in laboratory using the methods of [1] and that recommended by [2] and [3]. The results showed that the unconfined compressive strength of the samples under varying curing and soaking conditions ranged from $1217 \mathrm{kPa}$ to $265 \mathrm{kPa}$ while the durability indices were $59.51 \%$ and $59 \%$ respectively. Thus, the stabilizers have elevated the otherwise non-durable soil into the marginally durable zone.
\end{abstract}

Keywords: Black cotton soil, Durability, Sawdust ash, Stabilisation, Unconfined compressive strength

\section{INTRODUCTION}

In civil engineering, soils with properties that cannot be safely and economically used for the construction of civil engineering structures without adopting some stabilization measures are known as problem soils. These soils pose a problem to construction [4] as a result of their poor strength characteristics, and when such occurs, the engineer is left with the choice of borrowing suitable materials from other sites or to improve by means of stabilization the strength of the available soils [5]. When materials are imported to the site, the cost of construction becomes high due to delay in construction, increased haulage cost and time wastage, hence there is an option of adding stabilizing agents in order to improve the properties of the available soil using various soil improvement techniques $[6,7]$.

Black Cotton Soils (BCS), which are dark or sometimes grey coloured, are expansive clays found between $50^{\circ} \mathrm{N}$ and $45^{\circ} \mathrm{S}$ of the equator and are typical examples of such problem soils [8]. They are found predominantly in the North-Eastern part of Nigeria, in regions lying within the Chad Basin and partly within the Benue trough [8 - 10] When dry, Black Cotton Soils appear very hard with attendant high bearing capacity but when wet, Black Cotton
Soils absorb large volumes of water, swell rapidly and lose their high bearing capacity thereby leading to excessive settlement and failure of building structures and road pavements built on them. These geotechnical characteristics make Black Cotton Soils highly problematic when used as foundation for buildings and road pavements. This therefore underscores the various efforts being employed in order to successfully stabilise it with various additives $[8,11,12]$.

Although many reports have been generated on the successful stabilisation of BCS, It is essential to know the durability of such stabilised soils even when such a matrix can achieve acceptable levels of strength and stiffness under dry conditions, since it may have trouble in both achieving and sustaining adequate levels of strength required to maintain loads in a wet environments [13]. The durability of stabilised soil is therefore a measure of the resistance of the stabilised soil to moisture either in the form of freeze and thaw tests for temperate regions or in the form of durability index which is obtained from the ratio of the unconfined compressive strength (UCS) of immersed to non-immersed samples for nontemperate regions. Gutherie, et al [14] observed that the freeze-thaw procedure outlined in ASTM D560 is 
recommended for durability testing of cement-treated soils. This protocol involves subjecting specimens cured for 7 days in a fog room to 12 cycles of freezing and thawing. The procedures require freezing for 24 hours at a temperature not warmer than $-10^{\circ} \mathrm{F}$ and thawing for 23 hours at $70^{\circ} \mathrm{F}$ and 100 percent relative humidity. The vacuum saturation test also outlined in ASTM C593 is the durability test specified for lime-fly ash- and Class C fly ashstabilized soils. This procedure involves curing of specimens in a sealed condition for 7 days at $100^{\circ} \mathrm{F}$. Following curing, specimens are placed in a vacuum chamber that is subsequently evacuated to a pressure of $24 \mathrm{in.} \mathrm{Hg}$ (11.8 psi). After 30 minutes, the chamber is flooded with water, and the vacuum is removed. The specimens are allowed to soak for 1 hour and are then tested for UCS [14]. Another procedure being considered for use in durability testing of stabilized materials is the tube suction test, described in Texas Department of Transportation Test Method Tex-144-E (Tube Suction Test). This protocol requires subjection of cured, dried specimens to 10 days of capillary soaking and subsequent monitoring of surface dielectric values. Specimens having final average dielectric readings of less than 10 are considered satisfactory with respect to moisture/frost susceptibility, while specimens with final readings above 16 are considered unsatisfactory. Specimens with final dielectric values between 10 and 16 are expected to exhibit marginal long-term durability. Finally, the durability test method proposed by [2], and also described by [3] involves the curing one set of stabilized samples in a sealed container or an impermeable membrane for 7 days and subsequently soaking it in water for another 7 days while curing the second set of identical stabilized specimen in a similar impermeable membrane for 14 days. The durability index which is a ratio of the UCS of immersed to non immersed samples is used as a measure of durability. The durability of black cotton soil (BCS) subgrade stabilized with quarry fines (QF) and cement kiln dust (CKD) was studied by Amadi (2014) [15]. Using 10\% QF and five categories of cement kiln dust (CKD) concentration $(0 \%, 4 \%, 8 \%, 12 \%$ and $16 \%$ by dry weight of soil) he studied the durability of the said BCS using geotechnical parameters such as California bearing ratio (CBR) and UCS of immersed and non immersed samples as per (Ola, 1974) method. His results show that the UCS of soaked specimens containing $8-16 \%$ CKD attained $80-91 \%$ of the strength of control specimens and are therefore adjudged durable and suitable for use as subgrade. The specific objective of this study, therefore, is to evaluate the durability and stability of black cotton soil stabilised with a combination of $4 \%$ lime and $16 \%$ sawdust ash.

\section{MATERIALS AND METHODS}

\subsection{Materials}

\subsubsection{Black Cotton Soil}

The black cotton soil used in this study was obtained at Adamawa State Polytechnic, Yola, Adamawa State. It is located at latitude $9^{0} 14^{\prime} \mathrm{N}$ and longitude $12^{0} 28 \mathrm{E}$ of the Greenwich Meridian. The samples were collected as hand carved samples at a depth of $1 \mathrm{~m}$ below the ground surface after scraping off the top soil containing a lot of organic matter.

\subsubsection{Sawdust ash}

The burnt sawdust used as admixture in this project was sourced locally from a popular sawmill in Nsukka. The sawdust was collected with a spade from the heap of sawdust that is constantly generated from the operational sawing machine located beside it. The sawdust was bagged in a sack, transported to the laboratory and burnt in a furnace at a temperature of $800^{\circ} \mathrm{C}$. This burning which is typically different from that done by sawmills was done in a closed furnace so that the ash produced did not escape into the atmosphere and by implication yielding larger quantities of the ash with minimized environmental pollution.

\subsubsection{Lime}

Lime in the form of quicklime, $\mathrm{CaO}$ was used for the treatment of the soil-SDA mixture. Although the hydrated lime, $\mathrm{Ca}(\mathrm{OH})_{2}$ could be used, the lime in form of $\mathrm{CaO}$ offers the advantage of hydrating with the soil moisture to become hydrated lime thereby acting as a better drying agent before providing the calcium that will react with silica and alumina in the clayey soil.

\subsection{Methods}

BS1377 [16] was employed in the determination of the geotechnical properties of the natural black cotton soil. Oxide compostions of the natural black cotton soil as well as the sawdust ash were determined by using X-ray fluorescence. Subsequently, the maximum dry density and optimum moisture contents of the soil that is stabilised with a combination of $4 \%$ lime and $16 \%$ SDA were determined using the British standard 
light and the British standard heavy compaction method [16]. The mixtures were hand mixed thoroughly to ensure homogeneous mixture. The stabilization of soil with $4 \%$ lime and $16 \%$ SDA was chosen since it has proven to give the best results for compaction, CBR, Atterberg's limits and differential free swell tests $[17,18]$. The ASTM D559 [1] was used in this study for assessing the wetting and drying durability of the cured samples with the exception of wire brush application. The procedure involved submerging the compacted samples in potable water at room temperature for a period of 5 hours after which they are removed and the mass of the submerged samples recorded. The wetted samples were then placed in an oven at $71^{\circ} \mathrm{C}$ for 42 hours and the new weight obtained upon removal. This procedure constitutes one cycle (48 hours) of wetting and drying. This cycle is then repeated until the samples either fails or 12 cycles of wetting and drying is achieved, whichever comes first. A measure of the sample durability is achieved by obtaining a ratio of the UCS of the wetted and dried samples to that of 28 days cured samples that were not subjected to wetting and drying. Finally the method recommended by [2], and [3] already described above was also used for obtaining the stabilized sample durability which will also serve as a basis for comparison.

\section{RESULTS AND DISCUSSION}

\subsection{Geotechnical Properties of the Natural Black Cotton Soil}

Geotechnical properties of the natural black cotton soil used in this study are presented in Table 1 . It is evident from Table 1 that the BCS has a high clay content $(63 \%)$, high liquid limit $(82.6 \%)$ a very high plastic limit of $29.02 \%$ and plasticity index $53.4 \%$. According to Atterberg's classification of plasticity, a soil with plasticity index greater than 17 is adjudged to have a very high plasticity. Maximum dry density and CBR values for both soil specimens compacted with British standard light compaction and British standard heavy compaction are found to be low. Though the values obtained for the later mode of compaction is higher than the former mode of compaction, it is however insignificant as the values fell short of the minimum requirement of the Nigeria General specification (1997) for soils that should be used as subgrade materials. This explains why stabilization of the soil has to be performed before its use as subgrade material in road construction.
Table 1: Properties of black cotton soil

\begin{tabular}{|c|c|c|c|c|}
\hline S/No & \multicolumn{2}{|l|}{ Property } & Symbol & Value \\
\hline 1 & \multicolumn{2}{|l|}{ Gravel } & $\mathrm{G}$ & $0 \%$ \\
\hline 2 & \multicolumn{2}{|l|}{ Sand } & $\mathrm{S}$ & $12 \%$ \\
\hline \multirow[t]{2}{*}{3} & \multirow{2}{*}{\multicolumn{2}{|c|}{ Fines }} & Silt & $25 \%$ \\
\hline & & & Clay & $63 \%$ \\
\hline 4 & \multicolumn{2}{|l|}{ Liquid limit } & $\mathrm{W}_{\mathrm{L}}$ & $82.6 \%$ \\
\hline 5 & \multicolumn{2}{|l|}{ Plastic limit } & $W_{p}$ & $29.2 \%$ \\
\hline 6 & \multicolumn{2}{|l|}{ Plasticity Index } & $\mathrm{I}_{\mathrm{P}}$ & $53.4 \%$ \\
\hline 7 & \multicolumn{2}{|c|}{ Shrinkage Limit } & $\mathrm{W}_{\mathrm{S}}$ & $11.31 \%$ \\
\hline 8 & \multicolumn{2}{|c|}{ Soil Classification } & & $\mathrm{CH}$ \\
\hline 9 & \multicolumn{2}{|l|}{ Specific Gravity } & $\mathrm{G}_{\mathrm{S}}$ & 2.33 \\
\hline 10 & \multicolumn{2}{|c|}{ Differential Free Swell } & DFS & $74 \%$ \\
\hline \multirow[t]{2}{*}{11} & Optimum & BSL & O.M.C & $38 \%$ \\
\hline & $\begin{array}{l}\text { Moisture } \\
\text { Content }\end{array}$ & $\mathrm{BSH}$ & & $30 \%$ \\
\hline \multirow[t]{2}{*}{12} & Maximum Dry & BSL & M.D.D & $1.29 \mathrm{gm} / \mathrm{cc}$ \\
\hline & Density & BSH & & $1.478 \mathrm{gm} / \mathrm{cc}$ \\
\hline 13 & \multicolumn{3}{|c|}{ AASHTO classification } & $A-7-6[5]$ \\
\hline 14 & \multicolumn{2}{|l|}{ Colour } & & Black \\
\hline 15 & $\mathrm{pH}$ & & & 7.15 \\
\hline \multirow[t]{2}{*}{16} & \multirow{2}{*}{$\begin{array}{l}\text { CBR Value } \\
\text { (Soaked) }\end{array}$} & BSL & & 4.0 \\
\hline & & BSH & & 5.98 \\
\hline \multirow[t]{2}{*}{17} & \multirow{2}{*}{$\begin{array}{l}\text { CBR Value } \\
\text { (Unsoaked) }\end{array}$} & BSL & & 9.2 \\
\hline & & BSH & & 11.4 \\
\hline
\end{tabular}

\subsection{Oxide Composition of Materials}

Table 2 and Table 3 show the oxide composition of the BCS and the SDA respectively as obtained using the X-ray fluorescence. It is pellucid from Table 2 that the oxide composition of the black cotton soil is rich in silica $\left(\mathrm{SiO}_{2}\right)$ which could cause the soil to experience pozzolanic reaction when mixed with any pozzolanic admixture. In Table 3 showing the oxide composition of the admixture (SDA), it is glaring that its heavy metal composition is insignificant whilst containing $33.20 \%$ of $\mathrm{SiO}_{2}$ and $45.98 \%$ of $\mathrm{CaO}$. The SDA contain a high quantity of quicklime, $\mathrm{CaO}$ which could be necessary for both short term and long term (pozzolanic) reactions.

\subsection{Stress-Strain Curves of Cylindrical Specimens Cured At Different Duration of Days}

The stress-strain curves for samples obtained during the unconfined compression tests on the three categories of samples are shown in Figures 1 to 3 . Figure 1 represents stress-strain curves for samples cured at 7 days while Figures 2 to 3 represents samples cured at 14 and 28 days respectively. Generally, for all the curves in Figures 1-3, increase in the compressive stress was observed as the strain rate increased for all soil specimens with various days of curing until a peak value.

Vol. 38, No.1, January, 2019 
Table 2: Chemical composition of black cotton soil

\begin{tabular}{llllllllllllll}
\hline Oxides & $\mathrm{Al}_{2} \mathrm{O}_{3}$ & $\mathrm{SiO}_{2}$ & $\mathrm{SO}_{3}$ & $\mathrm{P}_{2} \mathrm{O}_{5}$ & $\mathrm{Na}_{2} \mathrm{O}$ & $\mathrm{K}_{2} \mathrm{O}$ & $\mathrm{CaO}$ & $\mathrm{MgO}$ & $\mathrm{TiO}_{2}$ & $\mathrm{Fe}_{2} \mathrm{O}_{3}$ & $\mathrm{MnO}$ & $\mathrm{L} .0 . \mathrm{I}$ & \\
\hline Chemical & 11.00 & 56.70 & $<0.001$ & $<0.001$ & 2.12 & 1.52 & 3.83 & 1.70 & 2.59 & 17.02 & 0.23 & 3.18 & \\
composition (\%) & & $\mathrm{Cr}$ & $\mathrm{Ni}$ & $\mathrm{Cu}$ & $\mathrm{Zn}$ & $\mathrm{Ga}$ & $\mathrm{Zr}$ & $\mathrm{Eu}$ & $\mathrm{Ir}$ & & $\mathrm{Re}$ & $\mathrm{In}$ & $\mathrm{Pb}$ \\
Trace elements & $\mathrm{V}$ & $\mathrm{Cr}$ & & & & \\
Composition (ppm) & 0.130 & 0.033 & 0.027 & 0.055 & 0.041 & 0.045 & $1 \%$ & 0.220 & $<0.001$ & & 0.100 & $<0.001$ & $<0.001$ \\
\hline
\end{tabular}

Table 3: Chemical composition of sawdust ash

\begin{tabular}{lllllllllllll}
\hline Oxides & $\mathrm{SiO}_{2}$ & $\mathrm{Al}_{2} \mathrm{O}_{3}$ & $\mathrm{SO}_{3}$ & $\mathrm{P}_{2} \mathrm{O}_{3}$ & $\mathrm{Na}_{2} \mathrm{O}$ & $\mathrm{K}_{2} \mathrm{O}$ & $\mathrm{CaO}$ & $\mathrm{MgO}$ & $\mathrm{TiO}_{2}$ & $\mathrm{Fe}_{2} \mathrm{O}_{3}$ & $\mathrm{MnO}$ & L.O.I \\
\hline Chemical composition (\%) & 33.20 & - & 3.81 & 2.20 & 1.38 & 10.65 & 45.98 & 1.20 & 0.50 & 0.03 & 1.01 & $\mathrm{~N} / \mathrm{A}$ \\
\hline & \multicolumn{8}{c}{$\mathrm{Trace}$ elements/Rare earth metals } \\
\hline Trace elements & $\mathrm{V}$ & $\mathrm{Cr}$ & $\mathrm{Ni}$ & $\mathrm{Cu}$ & $\mathrm{Zn}$ & $\mathrm{Sr}$ & $\mathrm{Yb}$ & $\mathrm{Zr}$ & $\mathrm{Eu}$ & $\mathrm{Hg}$ & $\mathrm{Rb}$ & $\mathrm{Pb}$ \\
\hline Composition (ppm) & 0.021 & $<0.001$ & $<0.001$ & 0.007 & 0.150 & 0.690 & $<0.001$ & 0.20 & 0.08 & 0.040 & - & 0.089 \\
\hline
\end{tabular}

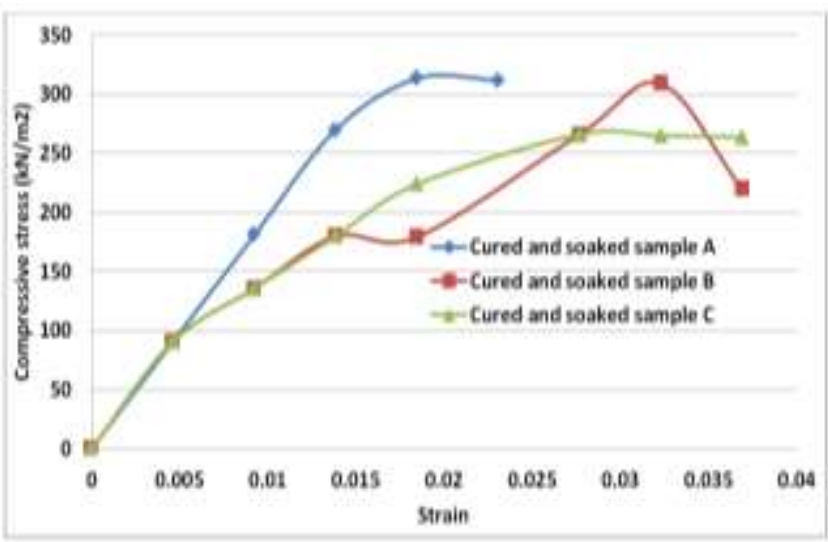

Figure 1: Stress-strain curves for cylindrical samples cured for 7days and soaked in water for 7days

The decrease observed thereafter in the compressive stress of the soil specimens after attaining its peak compressive stress value signified failure of the specimen. As noted earlier, the increase could be explicated in terms of the pozzolanic reaction that was experienced within the soil-lime-SDA mixture. The pozzolanic reactions resulted from the interactions of silica, alumina and lime present in the SDA as well as the $4 \%$ lime (calcium oxide) used also for the stabilization. When lime and water was added to the black cotton soil, chemical reactions occurred almost immediately as the lime became hydrated (quicklime). Reaction between lime and water gave rise to an exothermic reaction that subsequently resulted in the drying of the soil shortly after the release of heat. In addition, lime and water reaction led to the dissociation of the formed hydrated lime into its constituent ions $\left(\mathrm{Ca}^{2+}\right.$ and $\left.\mathrm{OH}^{-}\right)$. Black cotton

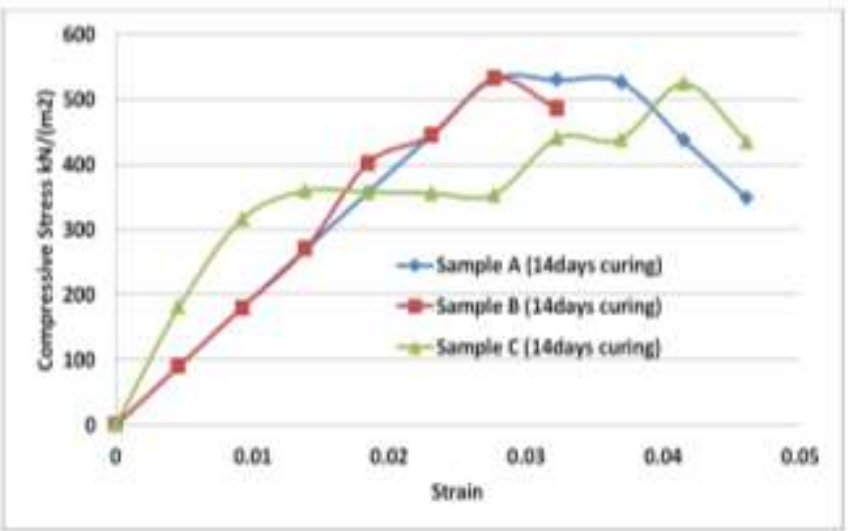

Figure 2: Variation of stress with strain for cylindrical samples cured for 14days

soil, which consists predominantly of montmorillonite, a clay mineral, tends to lose their hydrogen ion in the presence of moisture thus leaving a net negative charge on the surface of the clay particles. Dissociated calcium ions are attracted easily to the clay minerals that had net negative charge. The calcium ions reacts with the silica $\left(\mathrm{SiO}_{2}\right)$ or alumina $\left(\mathrm{Al}_{2} \mathrm{O}_{3}\right)$ present in clay and the hydroxyl ions present in the mixture leading to a more stable complexes formation (calcium silicate hydrate or calcium aluminate hydrate). At this stage the plasticity index as well as the tendency of the black cotton soil to swell and shrink is reduced drastically. This phenomenon is known as flocculation and agglomeration of the clay particles because the soil became friable and granular. The reactions are summarized thus:

$$
\begin{aligned}
& \mathrm{CaO}+\mathrm{H}_{2} \mathrm{O} \rightarrow \mathrm{Ca}(\mathrm{OH})_{2} \text { and } \mathrm{Ca}(\mathrm{OH})_{2} \rightarrow \mathrm{Ca}^{2+}+2\left(\mathrm{OH}^{-1}\right) \\
& \mathrm{Ca}^{2+}+2\left(\mathrm{OH}^{--}\right)+\mathrm{SiO}_{2} \text { (clay silica) } \longrightarrow \mathrm{CSH} \\
& \mathrm{Ca}^{2+}+2\left(\mathrm{OH}^{--}\right)+\mathrm{Al}_{2} \mathrm{O}_{3} \text { (clay alumina) } \longrightarrow \mathrm{CAH} \\
& \mathrm{Ca}^{2+}+2\left(\mathrm{OH}^{--}\right)+\mathrm{SiO}_{2} \text { (clay silica) }+\mathrm{Al}_{2} \mathrm{O}_{3} \text { (clay alumina) } \rightarrow \mathrm{CASH}
\end{aligned}
$$




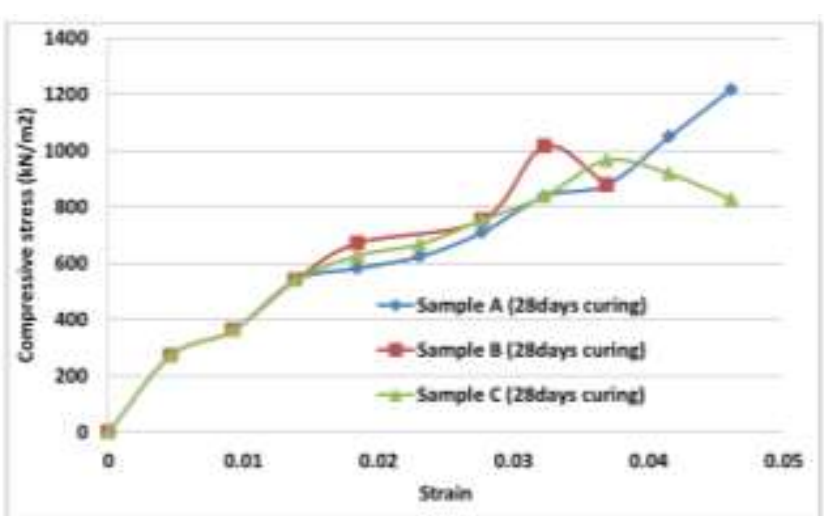

Figure 3: Variation of stress with strain for cylindrical samples cured for 28days

The calcium silicate hydrate and calcium aluminate hydrate cementitious compound formed are similar to those found in Portland cement. They form the matrix that contributed to the strength of the stabilised soil. As the matrix was formed, transformation of the soil from a sandy, granular material to a hard, relatively impermeable layer with significant load bearing capacity was observed. This process begins within hours and can continue for years in a properly designed system. The matrix formed is durable and significantly impermeable, producing a structural layer that is both strong and flexible $[19,20]$.

\subsection{Stress-strain curves for wetted and dried cylindrical samples}

Stress-strain curves for wetted and dried cylindrical soil specimens are presented in Figure 4. The strength of the wetted and dried samples also showed good results although only one of the samples survived the 12 cylces of wetting and drying. The other two lost shape at the $7^{\text {th }}$ cycle and thus were crushed in order to obtain its strength. The least values of strength were obtained from the samples cured for seven days and also soaked in water for 7days. The phenomenon buttresses the real life effect of sustained moisture infiltration on stabilised road bases, sub-bases and subgrades and thus shows that obtaining adequate values of CBR is

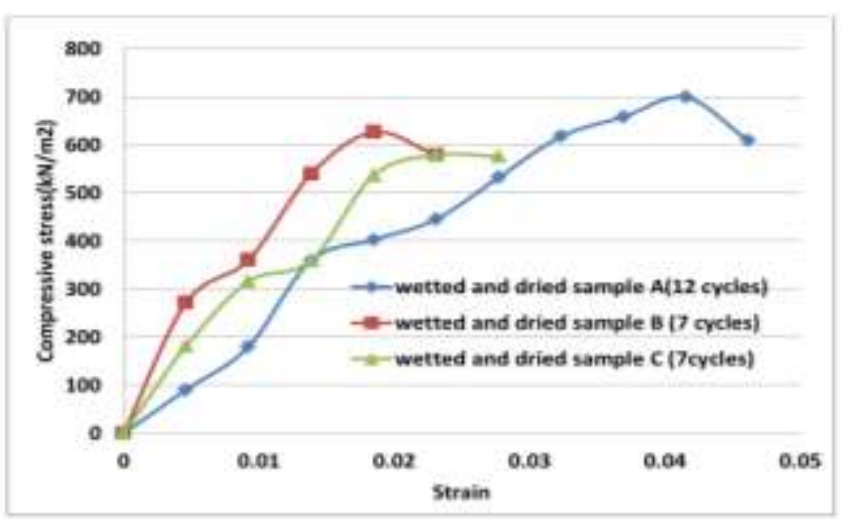

Figure 4: Stress-strain curves for wetted and dried cylindrical samples

in itself is not sufficient to guarantee the long term in-service performance of stabilised soils.

\subsection{Durability index of BCS stabilised with $4 \%$ lime and $16 \%$ SDA}

Table 4 show the durability index of BCS stabilised with $4 \%$ lime and $16 \%$ SDA using the criteria given by [1 - 3]. The durability of the stabilised soil is categorized as marginally durable as evinced from the Table 4. The durability index shows that resistance to loss in strength is more than $20 \%$ for both indexes. These values are higher than the maximum allowable $20 \%$ proposed by [21] which is often used in determination of the resistance to strength loss since the British standard [22] has unspecified value for it.

\section{CONCLUSION}

It can be seen from Table 4 that the engineering properties of BCS can be improved upon using a combination of $4 \%$ lime and $16 \%$ SDA. This combination elevates the durability index of the otherwise non-durable soil into the marginally durable zone. Although the stabilized soil did not meet the $80 \%$ durability index mark, which was recommended primarily for cement stabilized soils, it has however developed a marginal durability property for which field trials can be experimented upon since the north-eastern part of Nigeria, has limited rainfall.

Table 4: Durability index of BCS stabilised with 4\% lime and 16\% SDA

\begin{tabular}{lll}
\hline Durability index Criteria & Value & Designation \\
\hline Ola (1974) and BS 1924 (1990) & $59.00 \%$ & Marginally durable \\
ASTM D559 (2003) & $59.51 \%$ & Marginally durable \\
\hline
\end{tabular}




\section{REFERENCES}

[1] ASTM D 559, Standard test method for wetting and drying compacted soil-cement mixtures, ASTM International, West Conshohocken, PA, 1996.

[2] Ola, S. A. "Need for estimated cement requirements for stabilizing lateritic soils," Transportation Engineering, 1974.

[3] BS 1924; British Standard Institute, "Methods of tests for stabilized soils," 1990.

[4] Bolarinwa, A. and Ola, S. A. "A Review of the Major Problem Soils in Nigeria," FUOYE Journal of Engineering and Technology, vol. 1, no. 1, 2016.

[5] Oluyemi-Ayibiowu, B. D. and Owolabi, A. O. "Engineering Characteristics of Soils from Major Borrow Pits in Akure Town, Ondo State, Nigeria," Journal of Science and Technology Research, pp. 57-63, 2003.

[6] Megan, M. A., Ellis, S. J. and Mercer, J. "Use of Alternative Aggregates and Binders in Highway Construction in the UK," in Highways Agency, Department of Environment, Transportation Research Laboratory, Crowthorne, UK, 1999.

[7] Allan, F. R., Lynn, E. K. and H. M. Liljestrand, "Evaluation of Nontraditional Soil and Aggregate Stabilizers, Transportation Research Project Summary Report", Centre for Transportation Research, University of Texas, Austin Project Summary Report 7-1993-5, 2003.

[8] Osinubi, K. J., Ijimdiya, T. S. and Nmadu, I. "Lime stabilisation of black cotton soil using bagasse ash as admixture," Advances in materials and systems technologies II, vol. 62, no. 64, pp. 3-10, 2009.

[9] Ola, S. A., "Stabilisation of Maiduguri black cotton soils of Nigeria with sands," Bulletin of the International association of engineering geology, vol. 24, pp. 145-150, 1981.

[10] Nigerian Building and Road Research Institute, NIBBRI, Engineering properties of black cotton soils of Nigeria and related pavement design, NIBBRI Research papers, No. 1, 1983.

[11] Ali, M. S. and Korranne, S. S., "Performance analysis of expansive soil treated with stone dust and flyash," Electronics Journal of Geotechnical Engineering, vol. Bund I, no. 16, pp. 973-982, 2011.

[12] Ola, S. A., "The geotechnical properties of the black cotton soils of north-eastern Nigeria," in Tropical soils of Nigeria in engineering practice, Balkema, Rotterdam, pp. 85-101, 1983.

[13] Takeshi, K., Aly, A. and Keizo, U., "Durability of soft clay soil stabilised with recycled Bassanite and furnace cement mixtures," Soils and foundations, vol. 53, no. 1, pp. 155-165, 2013.

[14] Gutherie, W. S., Roper, B. M., and Eggett, L. D., Evaluation of laboratory durability tests for stabilised aggregate base materials, portland cement association, Transportation research board 87th Annual meeting, PCA R\&D Serial No. 3045, 2007.

[15] Amadi A. A., "Enhancing durability of quarry fines modified black cotton soil subgrade with cement kiln dust stabilization," Transportation Geotechnics 1 (2014) 55-61, 2014.

[16] Bristish Standard Institute, Methods of testing soils for civil engineering purposes, London: BS 1377, Part 41990.

[17] Ikeagwuani, C. C., "Stabilisation of black cotton soil with sawdust ash and lime for subgrade," MS thesis, Department of Civil Eng., Univ. of Nigeria, Nsukka, Enugu, 2013.

[18] Ikeagwuani, C. C., "Compressibility characterisitics of black cotton soil admixed with sawdust ash and lime," Nigerian Journal of Technology, vol. 35, no. 4, pp. 718-725, 2016.

[19] Arabi, M. and Wild, S., "Property changes induced in clay soils when using lime stabilisation," Municipal Engineer, London 6, pp. 85-99, 1989.

[20] Bell, F. G., "Lime stabilisation of clay minerals and soil," Engineering Geology, vol. 42, no. 4, pp. 223-237, 1996.

[21] Ola, S. A., "Geotechnical properties and behaviour of some stabilized Nigeria lateritic soils," Engineering Geology, vol. 12, pp. 145160, 1978.

[22] BS 1377, "Method of Testing Soils for Civil Engineering Purposes," in British Standard Institution, London, 1990. 